\title{
Cooperating Teachers' Expectations for Student Teachers During the Student Teaching Experience in Physical Education 實習教師在體育教學中的體會
}

\author{
Robert CHRISTENSON \\ Department of Applied Health \& Educational Psychology, \\ Oklahoma State University, U.S.A.
}

David BARNEY

Department of Teacher Education, Brigham Young University, U.S.A.

羅伯特基斯滕森

美國奧克拉荷馬州大學應用健康及教育心理學系

大衛賓尼

美國楊百翰大學教師教育學系

\begin{abstract}
The student teaching experience is important. The student teacher wants to be successful during their student teaching experience. Part of working successfully with the cooperating teacher can greatly impact a student teachers success. The purpose of this study was to investigate school based cooperative teachers' experiences with student teachers for the purpose of better preparing physical education teacher education majors for their student teaching. For this study 100 experienced physical educators were surveyed to find out what student teachers should expect to do to be successful when student teaching. One of the main findings from this study was for student teachers to successfully communicate with their cooperating teacher.
\end{abstract}

\section{摘 要}

實習教學的經驗是教師成功的要素。本研究的目的是調查實習教師與學校教師的經驗交流，共調查了100位具備豐富教學經 驗的體育教師, 結果顯示實習教師與本科教師溝通是最重要的因素。

\section{Introduction}

The culminating event for the majority of Physical Education Teacher Education (PETE) students is their student teaching experience. This usually serves as the transition between the university classroom and the first teaching position, allowing the student to put all the theory into practice. In addition, the experienced is one of the qualifiers for a teacher education student to gain their teaching endorsement for the state education department.

The students' education provides a wide variety of experiences that focus on content knowledge, instructional objectives, lesson planning, state and national standards, 
classroom management, teaching styles, instructional effectiveness, authentic assessments and providing an teaching-learning atmosphere that is both emotionally as well as physically safe. It is during the student teaching experience that these PETE student teachers have an opportunity to put into practice all that has been taught to them during their skills classes, methods classes, observation experiences, physical education pedagogy classes and practicum experiences. It is the student teaching experience that serves as a transition from the confines of the college classroom into the reality-based professional world of a school-based gymnasium.

The student teaching experience also serves as another component of the growth continuation where student teacher's character, maturity and professional attitude are challenged beyond their comfort zone. For example, students can create and implement lesson plans, develop instructional support materials, establish guided practice, implement different teaching styles in their lessons, assess student performance and communicate with parents. When PETE students are placed in the Pre K-12 school setting to fulfill their student teaching experience, it is hoped that they will be able to incorporate what they have been taught at the university level, blended with their own life-experiences and then, with the guidance of the school-based cooperative teacher, receive the mentoring necessary to have a successful experience that will lay the foundation to develop the self-confidence for a successful career as a physical educator.

As the PETE student teachers participate in their school-based experiences, there are several variables that can contribute to making it a successful experience. Some measure of success can be garnered by drawing from their own activity experiences as a participant along with their personal/professional character traits that have been developed over the years. As a result of being able to blend their upbringing, life experiences, theory lectures and participatory experiences, as well as emulating the lesson structures from their professional role models, the student teacher brings with them to their assignment the tools to respond to the needs of their students. It is the job of the PETE faculty to work with those personal/ professional characteristics and challenge the students to teach appropriate activities that will make a difference in a students' life.
Much of the literature dealing with the professional characteristics of student teachers has dealt primarily with and extrapolated from experienced teachers that have taught for five or more years in the classroom/gymnasium. Beishuizen, Hof, van Putten, Bouwmeester, and Asscher (2001) investigated what students thought about good teachers. The researchers found that elementary-aged students described a good teacher primarily as competent, where as secondary students emphasized having good relationships with students as being a good teacher.

Elder and Tamar (2006) conducted a study looking at characteristics of student teachers. In their study, they used a number of different methods of determining outstanding characteristics of student teachers. For example, they used psychometric tests, matriculation examinations, interviews of students, written evaluation from cooperative teachers and telephone interviews. This study was conducted in three distinct phases. The first phase took place at the beginning of the students' teacher preparation education. The second phase took place two years into their education program. The third phase took place about four year after the students had assumed their professional responsibilities as a teacher. The researchers reported that they found in the first phase of their study the interviews provided the best gauge for outstanding characteristics in student teachers. Those characteristics were their appearance, being able to think, their attitude towards the profession and their general content knowledge. In the second phase of the study, the researchers found the evaluations from the cooperative teachers to be helpful in identifying characteristics of student teachers. In the last phase, of the study, the researchers found that the student teachers, now full-time teachers, were pursuing master's degrees or were administrators in their schools. The researchers reported that the overall teaching ability, behavior in the class, social functioning, and critical thinking were important factors that the students identified as outstanding characteristics when found in the student teachers who were now practicing professionals.

Doolittle, Dodds, and Placek, (1993) have suggested that pre-service teachers come into a teacher education program with preconceived beliefs. Many of these notions about the teaching-learning process have been formulated through personal experiences, previous interaction with professionals, observations and their many years of experience in a school setting. Some of these preconceived beliefs of teaching physical education 
may not be appropriate or considered an effective use of instructional time, such as a heavy emphasis on competition in physical education class and team sports. If the current status of teacher preparation is as reported, PETE faculties have students for only two or three years to impact and possibly change these preconceived beliefs. Along with these predetermined viewpoints and attitudes about physical education that pre-service teachers bring to the teacher preparation program classes, each student begins their education with their own personality characteristics. These in many cases are more challenging to change, as each characteristic is a reflection of all their experiences.

The purpose of this study was to investigate school based cooperative teachers' experiences with student teachers. As a primary component of this investigation, the survey was designed to explore the school setting with hopes of playing a part in molding future professionals. The intention of gathering this information is to report on how PETE teacher candidates can be better prepared to work with their school-based cooperative teacher during the student teaching experience. A second reason, is to foster faculty members in PETE programs to understand the current dynamics in an effort to help reshape their lessons to be sure that each future professional has the character traits and teacher preparation qualities the school-based cooperating teachers are expecting when the student teacher arrives ready to take instructional control of classes.

\section{Methods}

\section{Subjects}

One hundred physical educators (28 males and 72 females) throughout the United States (15 states) participated in this study. For those physical educators who participated in this study, $82 \%$ had 10 years of more teaching experience. The Institutional Review Board (IRB) granted approval to conduct this study.

\section{Instrumentation}

A review of literature failed to identify an instrument related to cooperative teachers' expectations of student teachers. As such, the researcher constructed a survey instrument to investigate the school-based teacher's expectations for the student teacher as they arrive to begin their student teaching experience. The survey was constructed and underwent several revisions after having numerous conversations with university teacher education faculty, physical education faculty, as well as both elementary and secondary school-based physical educators. The survey consisted of 13 questions. In reviewing the 13 subject questions on the survey, four dealt with teacher demographics. Five were yes/no statements, with the opportunity for the teacher to explain their answer. Two were Likert scale questions, (one of the Likert scale breakdown for question seven was; very comfortable, moderately uncomfortable, neutral, moderately comfortable and totally comfortable. The other breakdown for question five was; 3 or fewer, 4-8; 9-15; and more than 16), and the other two questions required the teachers to write a response explaining their expectation of the student or program. To establish content validity, the researchers had four experienced physical educators from four different states review the survey, and found the statements from the survey to be valid. 
Table 1. Survey Regarding Physical Education Teachers' Expectations for Student Teachers Questions.

1. Current Position

2. Gender: Male Female

3. State Where You Teach:

4. Number of Years (or supervising physical education in your field).

$0-3$

$4-8$

9-15

More than 16

5. Approximate number of student teachers you have supervised in the past 20 years.

3 or fewer

$4-8$

9-15

More than 16

6. At any time, do you encourage/allow your student teacher to observe other settings/teachers?

YES NO

7. Your comfort level supervising student teachers.

Very Uncomfortable

Moderately Uncomfortable

Neutral

Moderately Comfortable

Totally Comfortable

8. What is your process for approving candidates?

9. Are you reluctant to completely turn over your classes to student teachers?

If you answered "YES", Please explain your answer.

10. Is physical education your primary certification area?

YES NO

11. Have you ever declined working with a student teacher, and if so, what personal and professional characteristics caused you to decline working with this student teacher in your school?

YES NO

12. After accepting a student teacher, have you ever requested a university to reassign an individual and is so based upon what personal and professional characteristics caused to request the change.

13. Are there any additional personal characteristics that you feel important that we have not touched upon in this survey?

\section{Procedures}

For this study, the researchers met with a member of the university instructional technology staff that helped create and place the survey on the Internet, so that it would be responder friendly. After the survey was placed on the Internet, the researchers, along with a graduate student sent out electronic messages to state (HPERD) association leaders in all fifty states who could be identified as school-based teachers soliciting their participation in the study. If for any reason the survey was mistakenly sent to someone on the college level or an individual who left school-based employment (i.e. retired), they were asked to forward the survey to another professional who was K-12 physical education teacher. After three months, the researchers collected the surveys that were completed and analyzed them. Results for this study are reported as percentages and as teacher comments. 


\section{Results}

The purpose of this study was to investigate the school-based cooperative teachers' experiences with student teacher as well as their expectations for these future professionals prior to their arrival at the school assignment. In addition, the results would help identify expectations for student teachers, for the purpose of helping to better shape the PETE program in an effort to better prepare student teacher candidates for their school-based experience. The data were analyzed using descriptive statistics in the Statistical Package for the Social Science (SPSS) 14.0 program. Percentages were used to reflect the K-12 physical education teachers' responses for each item being analyzed. The other method of data analysis was analyzing K-12 physical education teachers' responses to the questions from the survey. The researchers read and re-read the data until common themes became evident (O'Sullivan \& Tsangaridou, 1992).

The first four questions from the survey were demographic questions. Question five asked approximately how many student teachers they have supervised in the past 20 years. Twenty-one percent of the cooperative teachers have supervised three or fewer student teachers, $34 \%$ supervised 4-8 student teachers, 20\% supervised 915 student teachers, and $25 \%$ supervised more than 16 student teachers. Question six asked the cooperative teacher if at any time they encourage/allow the student teacher to observe other settings/teachers. Overwhelmingly, $99 \%$ of the cooperative teachers do encourage/allow the student teacher to observe other settings/teachers.

Question seven inquired of the level of comfort of supervising student teachers. It was found that $16 \%$ of the cooperative teachers were very uncomfortable having to supervise a student teacher. Yet, $69 \%$ of the cooperative teachers were totally comfortable with a student teacher teaching their students.

Question eight asked what process was used in approving student teacher candidates to participate in the student teaching experience. The most common procedure used in approving candidates was interviewing the candidate and reviewing materials submitted to the cooperative teacher. Another common procedure for approving candidates was when the student teacher candidate meets the university requirements. The school then accepts the request from the university. Another procedure of approving student teacher candidates is to review the student teachers materials, such as transcripts, a resume and student philosophy statement of teaching. One of the last procedural steps for accepting student teachers was having the individual complete a staterequired background check done in order to allow a student teacher to teach in their school.

Question nine asked the cooperative teacher if they were reluctant to completely turn over their classes to a student teacher. It was found that $20 \%$ of the cooperative teachers were reluctant to completely turn over their classes to a student teacher. Of those cooperative teachers that were reluctant, each briefly explained their reluctance. A common theme, as characterized by the response of one cooperative teacher was, "I am a person who likes to be in control. I just hope my class does not get out of control because then I have to retrain my students using the organizational structure I used with them prior to the student teacher." Another teacher stated, "Even when the student teacher takes over, I am not far away, listening to all that is said so that if a problem comes up they can get help quickly. " Many of the cooperative teachers' reluctance dealt with control issues in their classes.

Question 10 asked if physical education was the primary certification area of the cooperative teacher. Of those that responded, $79 \%$ said that physical education was the primary certification area. Question 11 asked the cooperative teachers if they have ever declined working with student teachers. The data revealed that $10 \%$ of the cooperative teachers have declined working with student teachers. The following statements represent categorical grouping (that were provided as reasons) for not accepting a request to place a student teacher. These included: 1) too busy with other teaching to add this responsibility; 2) not currently accepting; 3) I just finished a student teacher; 4) would not accept a student teacher from the institution-bad experienced; and 5) currently coaching and can not mentor a student teacher.

Question 12 asked the cooperative teachers if they have ever asked the university to reassign a student teacher based on personal characteristics. It was found that $11 \%$ answered 'yes' to this statement. The common responses from the cooperative teachers that explained their request for reassignment were, "frequent absences 
from their student teaching responsibilities", "touching students inappropriately", "created a very dangerous situation, repeatedly, by not supervising students", "poor classroom management skills", and "traveling too far caused several problems and the cooperating teacher felt a closer assignment would be better for the student teacher."

The final question, question 13, on the survey asked the school-based cooperative teachers if there are any additional personal or professional characteristics they feel are important that were not touched upon on the survey. From the list of personal and professional characteristics that were provided in the survey, the cooperative teachers responded with the following. They were: 1) professional attire, 2) grooming, 3) being flexible, 4) the student teacher's content knowledge, 5) increased contact between university faculty supervisors and school-based cooperative teacher with the student teacher (see Diagram 1), 6) classroom management skills, 7) communication skills with parents, 8) conflict resolution, 9) display/ poster/bulletin board preparation and displays, 10) stronger teacher presence in front of students, 11) controlling class activities with a loud voice or whistle, and 12) more familiarity with assessment procedures.

\section{Discussion}

The purpose of this study was to investigate cooperative teachers' experiences with student teachers as well as identify their expectations for future professionals, with the hope of creating stronger university-based PETE instructional scenarios for better preparing student teachers for their student teaching experience. When analyzing the data, it is apparent that PETE faculties need to know and understand what a cooperative teacher expects from student teachers. There was a common theme focused on communication between university faculty and the school-based cooperating teacher, recommending this needs to be a frequent occurrence during the teacher candidates student teaching experience.

One fact that was frequently expressed and as a result, needs to be highlighted, is that school-based cooperative teacher's feel they play an extremely important role in this transitional period for the student teacher. This key time period, commencing with the end of the qualification period of being a student-in-the-classroom to filling the professional responsibilities of a teacher in front of students, provides the opportunity to develop as well as shape many of their professional characteristics.
In many respects it has long been recognized as the most significant teaching-learning experience, but yet the university PETE faculty underutilizes it.

It was also clear, as a frequently identified from school-based cooperating teachers, the student teaching candidates would appear with an underdeveloped set of "neophyte/ immature/novice" personality skills and characteristics. Numerous responses included comments that conveyed both verbal and written reports were communicated to the professional preparation faculty expressing the need to work on the development of these character traits.

When the cooperative teachers were asked about working with student teachers, there were numerous responses that stated when they worked with a student teacher it was their way of giving back to the profession by sharing their experiences and knowledge with the future professionals. This phase in the student teacher's development was to a large extent responsible for shaping the student teacher's ideas, prior experiences and theories into usable organizational skills, practical instructional methods and real teaching progressions. As a result of the years of experiences, the teachers who serve as mentors also had a deep reservoir of ideas, experiences and responses to provide these future professionals. These experiences are in part, what make the schoolbased cooperating teacher such and integral working part, whose mentorship is priceless, in the education of the future professional physical education teacher education process.

Question six inquired if the cooperative teacher encouraged or allowed the student teacher to observe other settings and/or teachers. It appeared that almost all $(99 \%)$ of the cooperative teachers wanted and allowed the student teachers to observe other subject-area setting and/or additional teachers teach. One can deduce from these results that the cooperative teachers perceive physical education as well as teaching in general as a global experience. Other teachers have instructional skills and knowledge of the teaching-learning process that the student teacher can observe, gain knowledge from, and then apply what they learn to their own teaching.

When analyzing the responses from question seven, cooperative teachers comfort level supervising student teachers (Totally Comfortable 69\%; Moderately Comfortable 22\%; Neutral $0 \%$; Moderately Uncomfortable 2\%; Very 
Uncomfortable $7 \%$ and blending these with the results from question nine, an overwhelming majority reported no reluctance in turning over the responsibilities for their classes to student teachers. This response makes perfect sense since it is these teachers who volunteer their services to train future professionals. Several teachers responding to the survey reported directly or alluded to the quality of preparation by stating, "With the quality teachers that our university turns out I am not reluctant to turn my classes over to them!" The power of this response is further amplified when reviewing the reason for not relinquishing classes. Responses (Q9) such as 1) I provide mentoring by having new student teachers watch my teaching; 2) I believe it is a gradual process of shifting control; 3) I have them watch as I teach, then cooperatively plan, then team-teach and finally turn the class over to the student teacher as I observe and 4) I like to have the student teacher first observe my organizational skills along with my interactions with the students. As each individual demonstrates their ability to assume the leadership role, I allow them to take over. There is even the protective nature that was reported by school based cooperative teachers who had identified "difficult" classes and did not want student teachers' discouraged by unresponsive classes or students who are "unusually" disruptive to the teaching-learning process. There was also the "ever vigilant" professional that expressed the need to watch and listen in an effort to be prepared to provide feedback as well as make comments to strengthen the teaching awareness for the student teacher. While these responses were neither defensive nor questioning the quality of teaching skills of the student teachers, there were direct references to, as well as, inferences aimed at the school-based cooperating teacher's personal character trait of need to be in "control" of the class.

This feeling of responsibility was a recurring theme for many of the professionals responding to the survey. When cooperative teachers were asked regarding their comfort level of supervising student teachers, a small percentage stated that they were very uncomfortable. Question nine may have shed some light on why a very small number of cooperative teachers are very uncomfortable supervising student teachers. In the responses that school-based teachers expressed their reluctance, the basis for the negative feelings could be directly linked to their feeling of responsibility as well as their ego and their perception of the student teacher's ability to maintain the current status of class decorum. Question nine inquired if cooperative teachers were reluctant to completely turn over their classes to a student teacher. One thought to keep in mind is that these cooperative teachers have worked hard to establish and build their physical education programs. Thus, some of these cooperative teachers were reluctant to completely turn over their classes. Some cooperative teachers stated that they had negative experiences previously with student teachers, thus having a difficult time giving complete control of their classes to a student teacher.

Another negative aspect that came out of this study was that school-based cooperating teachers, under certain circumstances, declined to work with student teachers. The school-based cooperating teachers reported that this may have been the result of the student teacher expressing a disinterest in being a physical educator, but rather wanted to be a coach or in some other related field and had only selected physical education because of their athletic background. A small percentage of cooperative teachers requested the university to reassign the student teacher during their placement. The main factor for the cooperative teacher asking for a reassignment of the student teacher was an attitude of casualness.

\section{Conclusions}

Previous educational experiences can play a key role in the student teacher's perception of what the expectations are for the teaching of physical education. Even if their experience in physical education was positive enough to motivate them to become a physical education teacher, they might have been exposed to practices that are outdated, ineffective or inconsistent with NASPE appropriate practices. As a result of these inappropriate practices having been planted in their minds from years of exposure throughout their K-12 school education, PETE faculty need to reinforce appropriate practices along with professional expectations and personal character traits of their students. By focusing on these elements along with the content knowledge, teaching methods and experiences, PETE faculty can strengthen not only the instructional related skills but also the interpersonal character traits of these students who are focused on becoming physical education teachers. 
The transition from the university classroom to assuming a position in front of a room full of students in the gymnasium or other instructional area is a collaborative effort that takes a great deal of effort by everyone involved in the process. PETE faculty need to better understand school based expectations related to on-site performance, time commitments and involvement in job-related tasks during the on-site engagement for future professionals. It is also critically important that the PETE faculty grasps as well as communicate to the student teachers the critical role the schoolbased professionals play in the teaching/learning process. There are "teachable moments" that PETE faculty can not provide instruction for such as building emergency (fire drills or lockdowns), attendance procedures, student interactions, faculty meetings, playground supervision, bus duty and communications with parents which are everyday responsibilities for teachers. It is these types of field experiences that PETE faculty must rely on the schoolbased teachers to provide student teachers.

\section{Diagram 1. Instructional Pyramid.}

\section{Instructional Pyramid}

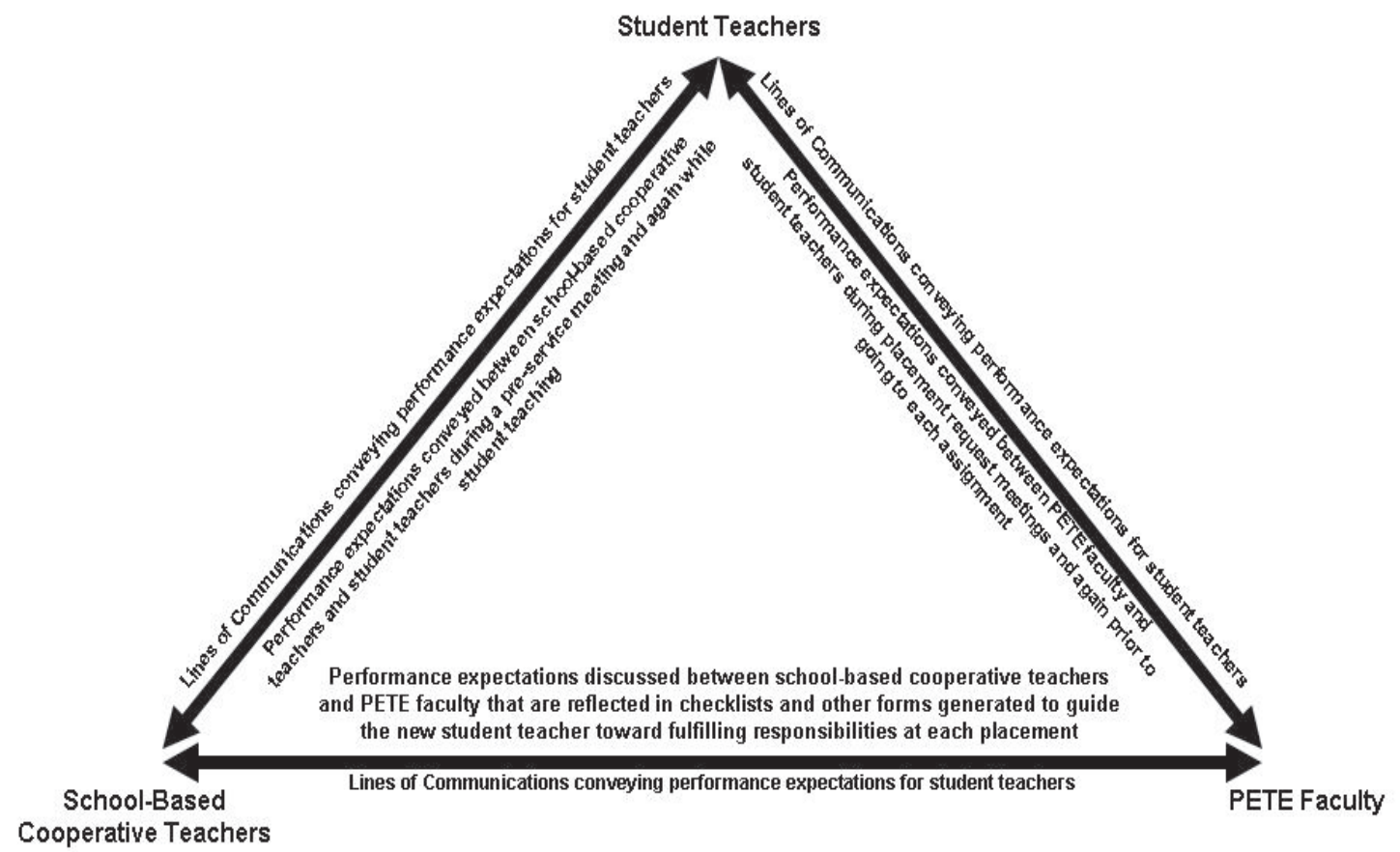

Most significant in this joint educational venture is the communication between the universities' PETE faculty members and schools because both are responsible for properly guiding students through the experiences of student teaching physical education. It is the flow of communication represented by this "Instructional Triangle" (see Diagram 1) that brings to light the important elements that must be agreed upon between PETE faculty, the student teachers and the school-based cooperating teachers. One element of communication in the Instructional Triangle deals with the university supervisor. The element of concern that was registered several times in the survey responses was when a university-based PETE faculty member does not personally work with the schoolbased cooperating teacher and/or the student teacher. In some cases education faculty, specifically what has been 
taught in class well as the performance expectations for the student teachers? This will give the university faculty a clearer picture of what to look for when watching the student teacher teach.

As practicing professionals who serve as mentors and supervisors, the sharing of experiences with a common theme for the student teachers during the various stages of their journey towards degree completion is essential. Every lesson planning episode, instructional experience, student assessment and teaching reflection that is explored, discussed, and strengthened though discussion increases the magnitude as well as the very critical nature of the communication between each of the parties.

The numerous respondents to the survey commented that while content knowledge; and instructional methodology were important expectations for all student teachers, it was those individuals who did not grasp the enormity of responsibility including lesson planning; how to interact with students and parents; resolving discipline problems; extra duty (bus) and supervision assignment (hall, lunch and playground and setting-up the area for instruction) that were rejected, reassigned or triggered the reluctance on the part of the teacher to turn over control of classes. In addition, several responses also focused on the need for discussions with student teachers regarding professional dress, being a strong presence with students and disarming their defensive attitude when discussing/ debriefing a lesson that needed adjustments.

It is as a result of these and other comments that there is a need strong recommendation made to understand that the cooperative teacher has a sense of giving back to the profession when there is an agreement reached to work with a student teacher. It shows pride in the profession and demonstrates a confidence what they do in their program and classes are good for the profession. The school-based cooperating teacher can give the student teacher an instructional blueprint from an already existing "quality program" that can be carried with them and inserted into their own program when they start their first teaching job. The responsibilities are great for both the PETE faculty and the schoolbased cooperating teacher as they prepare future physical educators. While not an element of this research, there were written comments that plainly referred to the employment process and the networking that results when a mature, well-spoken, instructionally sound, self-confident student teacher who can teach using a variety of teaching styles, meets and exceeds the demands of student teaching. It is the school-based cooperating teacher who serves as a professional reference when the student teacher is seeking that all important first job.

From this study, the analyzed data has given a better and much clearer picture of the responsibilities and how the cooperative teacher feels about working with student teachers. In addition, the results have also painted a new picture of the transfer of instructional power which for some of the cooperative teachers presents the relinquishing of control of their classes to a lesser experienced teacher. Some of the concerns of the teachers dealt primarily with reestablishing classroom management and getting their students back into the routines they had established prior to when the student teacher took over classes.

Another observation from the cooperative teachers was the student teachers need to understand the commitment that is associated with being a teacher. This encompasses all the classroom management, teaching methodology, administrative oversight and professional responsibilities that make up the day-to-day job of being a physical education teacher. The comments from the school-based cooperating teachers are clear that there is a critical need for student teacher to better understand the necessity for developing persona character traits, preparing lessons on time and a serious attitude adjustment from student to professional. In addition, there is a need for student teachers to fully grasp their new professional responsibilities and meet their time commitments, which exist while the individual serves as a student teacher. One comment, "student teacher need to grow-up fast and realize that everything they do in the school reflects back on me as a teacher in the building...especially the bad things, "best reflects the numerous statements recorded regarding the student teachers need to recognize and complete their responsibility. It was also a frequent response to have school-based teachers indicate that dead-lines were an issue when it came to submitting grades, filing discipline reports, completing lesson plans and meeting similar paperwork obligations. Increased contacts between the PETE faculty, the university faculty supervisors who work with student teachers while they are fulfilling their commitments in the schools and the school-based cooperating teacher can help to recognize, develop and reinforce the performance expectations for these job related responsibilities. 
From the results that have been presented from this study, the importance of the school-based cooperating teacher in continuing to shape a student teacher into a successful physical education teacher is reinforced. The university faculty must be conscious that their role in the teaching-learning process has not ended. It is during the student teaching experience when the transition towards becoming a professional is occurring that the student teacher is most open to accepting suggestions in the process. Each member of the student teaching "educational team" need to be mindful of teaching and exposing student teachers to appropriate teaching methods along with other positive practices that will have an impact on being a successful physical educator. It is clear from the responses received from the practicing school-based professionals, who are the on-the-scene professionals, that with both the cooperative teacher and PETE faculty working closer together, sharing observations on the student teacher as well as how to better prepare the student teacher for the school-based experiences on a much more regular basis, the chances are greater of producing top notch future professional physical educators who prepared to respond to the growing demands of physical educators today.

\section{References}

Beishuizen, J.J., Hof, E., van Putten, C.M., Bouwmeester, S., \& Asscher, J.J. (2001). Student's and teachers' cognition about good teachers. British Journal of Educational Psychology, 71, 185-201.

Doolittle, S.A., Dodds, P., \& Placek, J.H. (1993). Persistence of beliefs about teaching during formal training of preservice teachers. Journal of Teaching in Physical Education, 12, 355-365.

Eldar, E. \& Talmor, R. (2006). Characteristics of outstanding student teachers. Sport, Education, and Society, 11, (1), 55-72.

\section{Correspondence:}

David Barney, Ed.D.

Department of Teacher Education,

Brigham Young University

249 G Smith Field House

Provo, Utah 84602, U.S.A.

Email: David_Barney@byu.edu 